Article

\title{
Biomass Torrefaction as a Key Driver for the Sustainable Development and Decarbonization of Energy Production
}

\author{
Leonel J. R. Nunes $1,2,3,4,5, *$ (i) and João C. O. Matias ${ }^{4,5}$ (i) \\ 1 IPVC-Instituto Politécnico de Viana do Castelo, Rua da Escola Industrial e Comercial de Nun'Alvares, \\ 4900-347 Viana do Castelo, Portugal \\ 2 proMetheus-Unidade de Investigação em Materiais, Energia e Ambiente para a Sustentabilidade, \\ Instituto Politécnico de Viana do Castelo, Rua da Escola Industrial e Comercial de Nun'Alvares, 4900-347 \\ Viana do Castelo, Portugal \\ 3 ESA-Escola Superior Agrária, Refóios do Lima, 4990-706 Ponte de Lima, Portugal \\ 4 DEGEIT-Departamento de Economia, Gestão, Engenharia Industrial e Turismo, Universidade de Aveiro, \\ Campus Universitário de Santiago, 3810-193 Aveiro, Portugal; jmatias@ua.pt \\ 5 GOVCOPP_Unidade de Investigação em Governança, Competitividade e Políticas Públicas, \\ Universidade de Aveiro, Campus Universitário de Santiago, 3810-193 Aveiro, Portugal \\ * Correspondence: leonelnunes@ua.pt; Tel.: +351-258-909-740
}

Received: 16 December 2019; Accepted: 25 January 2020; Published: 27 January 2020

\begin{abstract}
Climate change is a reality that affects the daily lives of people around the world, with a set of effects that are systematically felt. If there is still discussion about the real cause behind these phenomena, with differing opinions defending the anthropic origin or the origin in terrestrial cycles of geological scale, it seems to be unanimously attributed to the increased concentration of greenhouse gases-particularly to $\mathrm{CO}_{2}$. That is, whatever the source of $\mathrm{CO}_{2}$, it is commonly accepted that this is the cause of the acceleration of the climate change process, and the occurrence of extreme climate phenomena. The use of energy from renewable sources, such as solar or wind, can contribute to the replacement of energy generated from fossil sources. However, these forms of energy are dependent on uncontrollable climatic factors and are, therefore, dependent on the existence of alternatives that, when in reserve, can be activated at any time as soon as the power grid requests their activation. Thus, biomass emerges as an alternative capable of providing this answer, although it also has numerous disadvantages. Torrefaction may be the technology that corrects these drawbacks and allows for the successful use of biomass in the replacement the coal used in power generation, contributing significantly to the reduction of $\mathrm{CO}_{2}$ emissions. In addition to this possibility, it is necessary to introduce forest management models that effectively make use of all material flows generated during forestry operations, creating value-added chains, with a view toward a circular economy and resource sustainability.
\end{abstract}

Keywords: forest waste management; climate change; biomass energy; torrefaction

\section{Introduction}

Today, humankind is facing what is most likely its greatest challenge ever $[1,2]$. This challenge, caused by its own inability to manage a growing need for material and energy resources, has led to a state of pressure on the environment, causing imbalances in the Earth's systems [3-5]. Of all these imbalances, the one suffering the most profound effects is the global climate system which-in addition to experiencing the simple seasonal changes that considerably affect the agricultural and forestry 
cycles-is also leading to frequent extreme weather phenomena, such as those being continually reported by the media worldwide [5-7].

Regardless of the ongoing discussion of the origin of the problem, with some contemporaries defending the occurrence of climate change as a problem related to natural phenomena associated with geological scale terrestrial cycles, or with other contemporaries who attribute any and all responsibility to anthropic activity, there is little doubt that at least the acceleration of these climate change processes stems from humankind's excessive release of greenhouse gases in its relentless pursuit of resources and energy [8-12].

Of all the greenhouse gases, the one that is primarily responsible and released in the largest volume is carbon dioxide $\left(\mathrm{CO}_{2}\right)[13,14]$. This gas, which naturally exists in the atmosphere, essentially results from combustion processes, and with the advent of the industrial revolution 200 years ago, fuels traditionally used in daily tasks, namely biomass, have been replaced by fossil fuels, which are much richer from the energy point of view, enabling the development of industry and society $[15,16]$.

The aim of this article is to review the processes associated with carbon dioxide emissions caused by the production of energy from fossil fuels, and which renewable alternatives can be used, notably for the substitution of coal, which is widely used for the production of electricity in coal-fired power plants. The process of converting solid biomass into energy first involves collecting the various wastes of which it is composed, possibly by a process of conversion into product, followed by transport to the places of consumption where the energy is used. The most common process is combustion for both heat and power production through thermochemical conversion, usually in cogeneration systems (Figure 1).

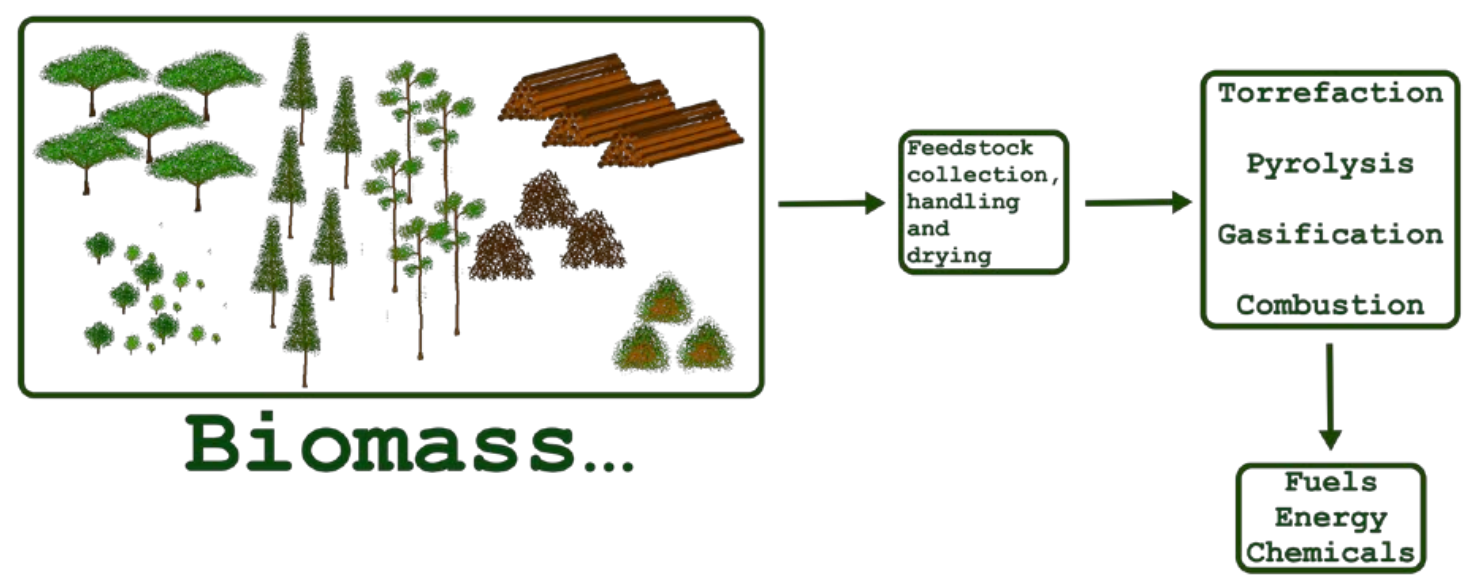

Figure 1. Several methodologies for converting forest biomass into energy and byproducts, where forest waste must play a very important role. In the definition of biomass, many other forms than forest biomass waste can be included, such as agricultural waste biomass or even industrial waste.

It is also intended to present the advantages of biomass torrefaction, which is a thermochemical conversion process that has the ability to standardize the properties of biomass, making them more consistent with those of coal. This article also addresses the need to create an integrated forest management model capable of creating a value chain that justifies the use of forest residues from forest management operations, associated with other supply chains, particularly those related to the pulp and paper industry and the wood panels industry, which use little or nothing of such waste by-products.

For the discussion presented here, after the bibliographical research on the themes, the analysis of the opinions expressed by other authors was made, allowing the establishment of a model that integrates the use of waste biomass as a sustainable energy alternative through the use of torrefaction technology, while also addressing the issue of creating an integrated forest management model and one which comprises forest resource management with the ability to capture and store carbon. 
From this perspective, this review article also intends to address the fact that one of the main advantages presented by several authors for torrefaction as a biomass pretreatment technology is its ability to homogenize different forms of biomass, thus making possible the use of residual forms, which are normally not part of the supply chains of bioenergy circuits. With this ability to use new forms of biomass, many of which have no commercial market value, production costs can be reduced significantly, thus making more competitive a process that, being more complex, is also more costly.

\section{Current Situation of Energy Production}

Fossil fuels, mainly coal, were first used for large-scale thermal energy production and later for the massive production of electric energy, whereas petroleum derivatives because they are more easily found in liquid or gaseous states, had particular applicability in the development of terrestrial, maritime, and air mobility $[17,18]$. However, now that the problem of their contribution to climate change has been identified, a solution that at least partly assists with climate change mitigation is urgently required [19]. As might be expected, there will be no simple, single solution, but rather a set of interconnected measures will be required to help to solve the problem [20]. That is, the solution in part involves the use of alternative renewable energy sources [21]. However, with current state-of-the-art technology, many types of renewable energy sources will be needed [22]. For example, both wind and solar energy are becoming increasingly efficient in terms of production, requiring less investment for their implementation. However, these energy types are dependent on weather factors, such as the occurrence of wind or the absence of cloudiness, to be generated [23]. In this scenario, biomass is an interesting alternative, as it allows the storage of energy that can be used once it is needed, thus meeting the demand of energy systems when other sources are not available [24]. Biomass can act as an energy reserve, or as a backup source that is used as soon as the system indicates a shortage [25].

Due to its heterogeneity, low density, low energy power, high moisture content, and territorial dispersion, the efficient use of biomass poses a set of challenges [26]. However, if properly processed and pretreated, biomass can be converted into a fuel, or rather a high-performance fuel package, capable of replacing any form of fossil fuel [27]. Depending on the conversion process used, an equivalent fuel can be obtained from biomass [27]. Examples include biodiesel, which is the renewable equivalent of diesel, and bioethanol, which is the renewable equivalent of gasoline. Concerning solid fuels, especially those with the potential to replace coal, several options have emerged, such as biomass pellets, which are products obtained from the drying, grinding, and subsequent densification of biomass particles into cylindrical shaped aggregates of variable diameter and length. This process creates homogeneous products with logistical advantages related to increased density and transportability [28,29].

Although these materials are already an alternative to coal, they cannot fully replace coal on a global scale due to several factors; notably, the differences in physical and chemical properties, such as hydrophilic properties opposed to the hydrophobicity of the coal, and the approximately $8 \mathrm{GJ} / \mathrm{t}$ difference in their heating values [30-32]. These two significant factors result, for the former, in the need for large investments by the end-user for the storage of biomass pellets to prevent them from degrading while waiting for use, and for the latter, the difference in heating values results in the mixing of the two fuels during co-firing process, creating too much turbulence in the flame, causing difficulties with maintaining efficient heat exchange [30,33].

Furthermore, other key issues must be addressed, such as high levels of halogens and alkali metals that enhance corrosion, slagging, and fouling phenomena in the combustion systems, causing unexpected and costly shutdowns, in addition to the need for the installation of a whole parallel system for the input of biomass pellets to the furnace $[30,34]$. Due to other differences in physical and chemical properties, the conventionally used system for coal cannot be used, requiring large investments for the conversion of coal-fueled power plants to biomass [30,34]. 


\section{Biomass Torrefaction}

Given this context, biomass torrefaction has emerged as an alternative capable of meeting the needs of a demanding energy market due to its ability to supply a final product according to the needs of coal users, as it is capable of directly replacing coal without the need for process changes, and therefore, prevents the need to invest significant amounts for the conversion of coal-fired power plants to biomass power plants [35]. Torrefaction can be defined as the thermochemical conversion process of biomass, occurring within a temperature range of 220 to $320^{\circ} \mathrm{C}$, at atmospheric pressure, in an oxygen-deficient environment, where the degradation of the constituent hemicellulose occurs with cellulose and lignin remaining [36-39]. This process eliminates volatile organic compounds and water, contributing to an increase in the fixed carbon content, and subsequently to the calorific value of the final product $[40,41]$. That is, torrefaction increases the energy density while effectively allowing the biomass to approximate the properties of coal [42-44].

This thermochemical conversion technology is capable of producing an excellent quality biomass fuel that meets all the requirements for efficient combustion $[42,45,46]$. This technology has considerable advantages over other biomass fuels, such as traditional pellets or chips, first because it results in a product with more calorific value per unit of mass; second, because it is hydrophobic and does not require physical structures for its storage; third, because all its physical properties are similar to coal and can, therefore, be used in the same combustion systems without major changes; fourth, because it remains a biomass fuel, which contributes to the carbon neutrality of energy production $[47,48]$.

\section{Torrefied Biomass and Coal}

Biomass torrefaction is one of the solutions for mitigating the effects of climate change, as it allows the replacement of one of the fossil fuels that underlies the problem [49]. Torrefied biomass, either pelletized or chipped, can be used to replace up to $100 \%$ of the coal used in the production of electricity, allowing for the conversion of coal-fired power plants to biomass plants but without the high financial investments required if the option was conversion to the use of non-thermally processed biomass pellets $[44,50,51]$.

The conversion of coal-fired power plants, in addition to the clear economic and environmental advantages, has an additional social benefit, as it will allow coal-fired power plants to continue their work beyond the period imposed by the forced closure determined by the various governments, thereby maintaining the many direct jobs related to the functioning of these units. It is, therefore, an option that embraces the three pillars of sustainability [52,53]. Table 1 shows in a simplified way the comparison between different forms of biomass, namely wood chips, wood pellets, and torrefied biomass, with coal for power production.

Table 1. Biomass properties for coal replacement.

\begin{tabular}{|c|c|c|c|c|}
\hline Properties & Coal & Wood Chips & Wood Pellets & Torrefied Biomass \\
\hline Moisture Content & $\begin{array}{l}\text { Naturally low in } \\
\text { moisture }\end{array}$ & High in water content & $\begin{array}{l}\text { Moderate water } \\
\text { content }\end{array}$ & Similar to coal \\
\hline Energy Content & High energy content & Low energy content & $\begin{array}{l}\text { Moderate energy } \\
\text { content }\end{array}$ & Similar to coal \\
\hline Handling and Logistics & $\begin{array}{l}\text { Low handling } \\
\text { requirements }\end{array}$ & Low bulk density & Moderate bulk density & $\begin{array}{l}\text { Can use existing } \\
\text { coal logistics }\end{array}$ \\
\hline $\mathrm{CO} 2$ Emissions & Fossil Fuel & $\begin{array}{l}\text { Carbon-neutral } \\
\text { renewable fuel }\end{array}$ & $\begin{array}{l}\text { Carbon-neutral } \\
\text { renewable fuel }\end{array}$ & $\begin{array}{l}\text { Carbon-neutral } \\
\text { renewable fuel }\end{array}$ \\
\hline Required Investments & $\begin{array}{l}\text { Low processing } \\
\text { requirements }\end{array}$ & $\begin{array}{l}\text { Requires logging and } \\
\text { chipping }\end{array}$ & $\begin{array}{c}\text { Requires chipping and } \\
\text { densification }\end{array}$ & $\begin{array}{l}\text { Can use existing } \\
\text { coal infrastructure }\end{array}$ \\
\hline $\begin{array}{l}\text { Co-Firing Ratio } \\
\text { with Coal }\end{array}$ & $\mathrm{N} / \mathrm{A}$ & $\begin{array}{l}\text { Low co-fire ratios due } \\
\text { to low bulk density }\end{array}$ & Up to $15 \%$ & Up to $50 \%$ or more \\
\hline
\end{tabular}

\section{Forest Management from the Supply of Biomass to Energy Perspective}

From this perspective-and because biomass torrefaction is a technology that enables the standardization of different types of biomass, thus allowing the use of a wider range of plant 
species-biomass torrefaction could also play a key role in the eradication and control of invasive species, which may be classified as a resource, but also by the contribution to the clearing of the forest space, specifically in the elimination of residues resulting from forestry operations [54,55]. Thus, the production of energy products does not conflict with the market for raw materials for other industries, namely pulp and paper and wood pellets, and also contributes to reducing the risk of forest fires by decreasing the permanent fuel load [56,57].

Creating a value-added supply chain for forest products requires the development of a new mindset for the forest sector around the world, as this is the only way that biomass can be a sustainable energy alternative from a circular economy perspective; where all materials are used, creating value along the supply chain and enabling the settlement of rural populations [58,59].

The possibility of exploiting forests dedicated to energy production is also a potential alternative, especially in the case of the conservationist management of carbon levels, ensuring that the amount of carbon released by energy recovery remains neutral by planting a new area equivalent to that used [60]. This conservationist view leads to the verticalization of the forest management model, where the energy recovery units have upstream dedicated production forests with species selected for biomass production, preferably in a multi-crop regime with the interleaving of different species, chosen for the same purpose [61]. As such, the problems related to the use of monocultures are avoided. These problems mainly arise due to the lack of resilience in this type of forest management. An example of this is the spread of pests and diseases that, when they reach an area with vulnerable species, can progress quickly, causing damage and losses [62].

If properly managed, a dedicated multi-crop forest where the hydrological and nutrients cycles are maintained, with sufficiently long rotation periods to ensure carbon conservation through efficient capture and sequestration, has many advantages, mainly because the fuel supply process can be continually and permanently vertically integrated $[63,64]$. The combination of forests dedicated to the production of biomass for energy and the use of surplus material resulting from forestry operations for other purposes will ensure the viability of the material supply model for the conversion to fuels or to direct energy recovery $[63,65]$.

\section{Conclusions and Future Developments}

Climate change is a set of phenomena that have a direct impact on daily activities, highlighting the changes that affect the growth cycle of both agricultural and forest crops. From all the measures necessary to mitigate climate change-the use of renewable energy sources that may be an alternative to the use of fossil fuels emerges as one that may, perhaps, contribute more quickly and effectively to the reduction of $\mathrm{CO}_{2}$ emissions. Torrefaction is a technology capable of transforming waste biomass-resulting from forest, agricultural, or industrial activities-into biomass-derived fuels, capable of directly replacing coal in electricity generation, especially if it comes from forests designed to function as carbon sinks.

Torrefaction is a technology that can serve as a basis for the development of other technologies, by acting as a preprocessing technology prior to the use of other processes, whether for energy production or for biorefineries for green chemicals. Many cases can already be found in the literature of the biomass gasification and liquefaction processes used to obtain these products. One of the most promising cases is the production of hydrogen from biomass gasification, which is thought to allow the development of a new form of mobility based on electricity-driven systems, but without the constraints inherent in the use of batteries, as is currently the case.

Despite all the advantages presented for biomass torrefaction, mainly with regard to its ability to homogenize different types of raw materials, this technology still presents some constraints, namely regarding its scalability and the capacity of large units to operate continuously. Many recent developments have been achieved, mainly in terms of process control and stability, a fact that has enabled the production of high-quality products. However, it cannot yet be considered as a mature technology, so a large investment in R\&D is still needed. 
The use of torrefaction as a pretreatment technology allows the gasification process to be much more efficient than when starting from thermally unprocessed biomass. The production of more advanced forms of materials with high fixed carbon contents, such as charcoal, coke, and activated charcoal, are also promising possibilities that will aid with the development of new nanotechnology products, for example, by supplying carbon for the production of graphene, or activated charcoal for the removal of toxic compounds.

Author Contributions: Conceptualization, L.J.R.N. and J.C.O.M.; methodology, L.J.R.N.; validation, J.C.O.M.; writing-original draft preparation, L.J.R.N.; writing-review and editing, J.C.O.M.; supervision, J.C.O.M. All authors have read and agreed to the published version of the manuscript.

Funding: This research received no external funding.

Acknowledgments: Authors declare no need of further acknowledgments.

Conflicts of Interest: The authors declare no conflict of interest.

\section{References}

1. Kennedy, P. Global challenges at the beginning of the twenty-first century. Adult Educ. Dev. 2000, 7-20.

2. Wackernagel, M.; Rees, W. Our Ecological Footprint: Reducing Human Impact on the Earth; New Society Publishers: Gabriola Island, BC, Canada, 1998.

3. Walker, J.C.G.; Hays, P.B.; Kasting, J.F. A negative feedback mechanism for the long-term stabilization of Earth's surface temperature. J. Geophys. Res. Space Phys. 1981, 86, 9776. [CrossRef]

4. Hansen, J.; Nazarenko, L.; Ruedy, R.; Sato, M.; Willis, J.; Del Genio, A.; Koch, D.; Lacis, A.; Lo, K.; Menon, S.; et al. Earth's Energy Imbalance: Confirmation and Implications. Sci. 2005, 308, 1431-1435. [CrossRef] [PubMed]

5. Penuelas, J.; Poulter, B.; Sardans, J.; Ciais, P.; Van Der Velde, M.; Bopp, L.; Boucher, O.; Godderis, Y.; Hinsinger, P.; Llusià, J.; et al. Human-induced nitrogen-phosphorus imbalances alter natural and managed ecosystems across the globe. Nat. Commun. 2013, 4, 2934. [CrossRef] [PubMed]

6. Tipper, E.T.; Gaillardet, J.; Galy, A.; Louvat, P.; Bickle, M.J.; Capmas, F. Calcium isotope ratios in the world's largest rivers: A constraint on the maximum imbalance of oceanic calcium fluxes. Glob. Biogeochem. Cycles 2010, 24. [CrossRef]

7. Carnicer, J.; Sardans, J.; Stefanescu, C.; Ubach, A.; Bartrons, M.; Asensio, D.; Penuelas, J. Global biodiversity, stoichiometry and ecosystem function responses to human-induced C-N-P imbalances. J. Plant Physiol. 2015, 172, 82-91. [CrossRef]

8. Sundquist, E.T. Geological perspectives on carbon dioxide and the carbon cycle. In The Carbon Cycle and Atmospheric CO2: Natural Variations Archean to Present. Proceedings of the Chapman Conference on Natural Variations in Carbon Dioxide and the Carbon Cycle, Tarpon Springs, FL, USA, 9-13 January 1984; Washington DC American Geophysical Union Geophysical Monograph Series; John Wiley \& Sons, Inc.: Hoboken, NJ, USA, 1985; Volume 32, pp. 55-59.

9. Arthur, M.A. The carbon cycle-controls on atmospheric $\mathrm{CO} 2$ and climate in the geologic past. Climate earth history 1982, 1, 55-67.

10. Fricke, H.C.; $\mathrm{O}^{\prime}$ Neil, J.R. The correlation between $18 \mathrm{O} / 16 \mathrm{O}$ ratios of meteoric water and surface temperature: its use in investigating terrestrial climate change over geologic time. Earth Planet. Sci. Lett. 1999, 170, 181-196. [CrossRef]

11. De Larminat, P. Earth climate identification vs. anthropic global warming attribution. Annu. Rev. Control. 2016, 42, 114-125. [CrossRef]

12. Rodrigues, M.G.; Da Costa, F.J.P. Climate Changes, Uncertainties and Contradictions: Toward the Responsible Attitude before Environment. Rev. Int. Ciências 2015, 5, 127-149. [CrossRef]

13. Pastor, J.; Post, W.M. Response of northern forests to CO2-induced climate change. Nature 1988, 334, 55-58. [CrossRef]

14. Zavaleta, E.S.; Shaw, M.R.; Chiariello, N.R.; Mooney, H.A.; Field, C.B. Additive effects of simulated climate changes, elevated CO2, and nitrogen deposition on grassland diversity. Proc. Natl. Acad. Sci. USA 2003, 100, 7650-7654. [CrossRef] [PubMed] 
15. Govindasamy, B.; Caldeira, K.; Duffy, P. Geoengineering Earth's radiation balance to mitigate climate change from a quadrupling of CO2. Glob. Planet. Chang. 2003, 37, 157-168. [CrossRef]

16. Dai, A.; Meehl, G.A.; Washington, W.M.; Wigley, T.M.L.; Arblaster, J.M. Ensemble Simulation of Twenty-First Century Climate Changes: Business-as-Usual versus CO2Stabilization. Bull. Am. Meteorol. Soc. 2001, 82, 2377-2388. [CrossRef]

17. Kempton, W.; Tomić, J. Vehicle-to-grid power implementation: From stabilizing the grid to supporting large-scale renewable energy. J. Power Sources 2005, 144, 280-294. [CrossRef]

18. Buhre, B.; Elliott, L.; Sheng, C.; Gupta, R.; Wall, T. Oxy-fuel combustion technology for coal-fired power generation. Prog. Energy Combust. Sci. 2005, 31, 283-307. [CrossRef]

19. Change, I.P.O.C. Climate Change 2014: Mitigation of Climate Change by Intergovernmental Panel on Climate Change. In Climate Change 2014 Mitigation of Climate Change; Cambridge University Press (CUP): Cambridge, UK, 2014; Volume 1454.

20. Myhrvold, N.P.; Caldeira, K. Greenhouse gases, climate change and the transition from coal to low-carbon electricity. Environ. Res. Lett. 2012, 7, 014019. [CrossRef]

21. Hayhoe, K.; Kheshgi, H.S.; Jain, A.K.; Wuebbles, D.J. Substitution of Natural Gas for Coal: Climatic Effects of Utility Sector Emissions. Clim. Chang. 2002, 54, 107-139. [CrossRef]

22. Williams, R.H. Toward zero emissions from coal in China. Energy Sustain. Dev. 2001, 5, 39-65. [CrossRef]

23. Bird, L.; Lew, D.; Milligan, M.; Carlini, E.M.; Estanqueiro, A.; Flynn, D.; Gomez-Lazaro, E.; Holttinen, H.; Menemenlis, N.; Orths, A.; et al. Wind and solar energy curtailment: A review of international experience. Renew. Sustain. Energy Rev. 2016, 65, 577-586. [CrossRef]

24. Andreae, M.O. Biomass burning: Its history, use and distribution and its impact on environmental quality and global climate. In Global Biomass Burning: Atmospheric, Climatic and Biospheric Implications; Levine, J.S., Ed.; MIT Press: Cambridge, MA, USA, 1991; pp. 3-21.

25. Berndes, G.; Hoogwijk, M.; Broek, R.V.D. The contribution of biomass in the future global energy supply: A review of 17 studies. Biomass Bioenergy 2003, 25, 1-28. [CrossRef]

26. Heller, M.C.; A Keoleian, G.; Mann, M.K.; A Volk, T. Life cycle energy and environmental benefits of generating electricity from willow biomass. Renew. Energy 2004, 29, 1023-1042. [CrossRef]

27. Klass, D.L. Biomass for Renewable Energy, Fuels, and Chemicals; Elsevier: Cambridge, MA, USA, 1998.

28. Bildirici, M.E. Economic growth and biomass energy. Biomass Bioenergy 2013, 50, 19-24. [CrossRef]

29. Bies, L. The Biofuels Explosion: Is Green Energy Good for Wildlife? Wildl. Soc. Bull. 2006, 34, $1203-1205$. [CrossRef]

30. Nunes, L.; Matias, J.; Catalão, J.P.S. A review on torrefied biomass pellets as a sustainable alternative to coal in power generation. Renew. Sustain. Energy Rev. 2014, 40, 153-160. [CrossRef]

31. Rodrigues, A.; Loureiro, L.; Nunes, L. Torrefaction of woody biomasses from poplar SRC and Portuguese roundwood: Properties of torrefied products. Biomass Bioenergy 2018, 108, 55-65. [CrossRef]

32. Nunes, L.J.; Matias, J.C.D.O.; Catalao, J.P.D.S. Torrefaction of Biomass for Energy Applications: From Fundamentals to Industrial Scale; Academic Press: Cambridge, MA, USA, 2017.

33. Nunes, L.; Matias, J.; Catalão, J.P.S. Biomass waste co-firing with coal applied to the Sines Thermal Power Plant in Portugal. Fuel 2014, 132, 153-157. [CrossRef]

34. Nunes, L.; Matias, J.; Catalão, J.P.S. Wood pellets as a sustainable energy alternative in Portugal. Renew. Energy 2016, 85, 1011-1016. [CrossRef]

35. Viana, H.; Rodrigues, A.; Lopes, D.; Godina, R.; Nunes, L.; Matias, J. Pinus Pinaster and Eucalyptus Globulus Energetic Properties and Ash Characterization. In Proceedings of the 2018 IEEE International Conference on Environment and Electrical Engineering and 2018 IEEE Industrial and Commercial Power Systems Europe (EEEIC / I\&CPS Europe), FEUP, Porto, Portugal, 12-15 June 2018; Institute of Electrical and Electronics Engineers (IEEE): Piscataway, NJ, USA, 2018; pp. 1-4.

36. Nunes, L.; Godina, R.; Matias, J.; Catalão, J. Torrefaction of Portuguese woody biomasses and the evaluation of its properties. In Proceedings of the International Conference on Renewable Energies and Power Quality (ICREPQ'18), Salamanca, Spain, 21-23 March 2018; EA4EPQ—University of Vigo and University of Granada: Vigo, Spain, 2018.

37. Ribeiro, J.M.C.; Godina, R.; Matias, J.C.D.O.; Nunes, L.J.R. Future Perspectives of Biomass Torrefaction: Review of the Current State-Of-The-Art and Research Development. Sustainability 2018, 10, 2323. [CrossRef] 
38. Tumuluru, J.S.; Sokhansanj, S.; Hess, J.R.; Wright, C.T.; Boardman, R.D. REVIEW: A review on biomass torrefaction process and product properties for energy applications. Ind. Biotechnol. 2011, 7, $384-401$. [CrossRef]

39. Prins, M.J. Thermodynamic Analysis of Biomass Gasification and Torrefaction. Ph.D. Thesis, Eindhoven University of Technology, Eindhoven, The Netherlands, 2005.

40. Ren, S.; Lei, H.; Wang, L.; Bu, Q.; Chen, S.; Wu, J. Thermal behaviour and kinetic study for woody biomass torrefaction and torrefied biomass pyrolysis by TGA. Biosyst. Eng. 2013, 116, 420-426. [CrossRef]

41. Bates, R.B.; Ghoniem, A.F. Biomass torrefaction: Modeling of reaction thermochemistry. Bioresour. Technol. 2013, 134, 331-340. [CrossRef] [PubMed]

42. Rodrigues, A.; Nunes, L.; Godina, R.; Matias, J. Correlation between Chemical Alterations and Energetic Properties in Torrefied Biomass. In Proceedings of the 2018 IEEE International Conference on Environment and Electrical Engineering and 2018 IEEE Industrial and Commercial Power Systems Europe (EEEIC / I\&CPS Europe), FEUP, Porto, Portugal, 12-15 June 2018; Institute of Electrical and Electronics Engineers (IEEE): Piscataway, NJ, USA, 2018; pp. 1-5.

43. Batidzirai, B.; Mignot, A.; Schakel, W.; Junginger, H.; Faaij, A. Biomass torrefaction technology: Techno-economic status and future prospects. Energy 2013, 62, 196-214. [CrossRef]

44. Li, J.; Brzdekiewicz, A.; Yang, W.; Blasiak, W. Co-firing based on biomass torrefaction in a pulverized coal boiler with aim of 100\% fuel switching. Appl. Energy 2012, 99, 344-354. [CrossRef]

45. Nunes, L.J.; Godina, R.; Matias, J.C.; Catalão, J.P. Evaluation of the utilization of woodchips as fuel for industrial boilers. J. Clean. Prod. 2019, 223, 270-277. [CrossRef]

46. Wang, G.; Luo, Y.; Deng, J.; Kuang, J.; Zhang, Y. Pretreatment of biomass by torrefaction. Chin. Sci. Bull. 2011, 56, 1442-1448. [CrossRef]

47. Loureiro, L.M.; Nunes, L.J.; Rodrigues, A.M. Woody biomass torrefaction: fundamentals and potential for Portugal. Silva Lusit. 2017, 25, 35-63.

48. Nunes, L.J.; Godina, R.; Matias, J.C. Characterization and Possible Use to Fly Ashes from Anthracite Combustion in a Thermal Power Plant. In Proceedings of the 2018 IEEE International Conference on Environment and Electrical Engineering and 2018 IEEE Industrial and Commercial Power Systems Europe (EEEIC / I\&CPS Europe), FEUP, Porto, Portugal, 12-15 June 2018; Institute of Electrical and Electronics Engineers (IEEE): Piscataway, NJ, USA, 2018; pp. 1-4.

49. Bergman, P.C.; Boersma, A.; Zwart, R.; Kiel, J. Torrefaction for Biomass Co-Firing in Existing Coal-Fired Power Stations; Energy Centre of Netherlands: Maartensvlotbrug, The Netherlands, 2005; Report No. ECN-C-05-013.

50. Ciolkosz, D.; Wallace, R. A review of torrefaction for bioenergy feedstock production. Biofuels Bioprod. Biorefining 2011, 5, 317-329. [CrossRef]

51. Du, S.-W.; Chen, W.-H.; Lucas, J.A. Pretreatment of biomass by torrefaction and carbonization for coal blend used in pulverized coal injection. Bioresour. Technol. 2014, 161, 333-339. [CrossRef]

52. Guo, F.; Zhong, Z. Co-combustion of anthracite coal and wood pellets: Thermodynamic analysis, combustion efficiency, pollutant emissions and ash slagging. Environ. Pollut. 2018, 239, 21-29. [CrossRef]

53. Phanphanich, M.; Mani, S. Impact of torrefaction on the grindability and fuel characteristics of forest biomass. Bioresour. Technol. 2011, 102, 1246-1253. [CrossRef] [PubMed]

54. Xu, Y.; Wang, Y.; Chen, Y.; Tian, C.; Feng, Y.; Li, J.; Zhang, G. Characterization of fine and carbonaceous particles emissions from pelletized biomass-coal blends combustion: Implications on residential crop residue utilization in China. Atmos. Environ. 2016, 141, 312-319. [CrossRef]

55. Nunes, L.J.R.; Meireles, C.I.R.; Gomes, C.J.P.; Ribeiro, N.M.C.A. The Evolution of Climate Changes in Portugal: Determination of Trend Series and Its Impact on Forest Development. Climate 2019, 7, 78. [CrossRef]

56. Nunes, L.J.R.; Meireles, C.I.R.; Gomes, C.J.P.; Ribeiro, N.M.C.D.A. Socioeconomic Aspects of the Forests in Portugal: Recent Evolution and Perspectives of Sustainability of the Resource. Forests 2019, 10, 361. [CrossRef]

57. Chen, W.-H.; Peng, J.; Bi, X.T. A state-of-the-art review of biomass torrefaction, densification and applications. Renew. Sustain. Energy Rev. 2015, 44, 847-866. [CrossRef]

58. Thiffault, E.; Endres, J.; McCubbins, J.S.; Junginger, M.; Lorente, M.; Fritsche, U.; Iriarte, L. Sustainability of forest bioenergy feedstock supply chains: Local, national and international policy perspectives. Biofuels Bioprod. Biorefining 2015, 9, 283-292. [CrossRef] 
59. Godina, R.; Nunes, L.J.R.; Santos, F.M.B.C.; Matias, J.C.O. Logistics cost analysis between wood pellets and torrefied Biomass Pellets: The case of Portugal. In Proceedings of the 2018 7th International Conference on Industrial Technology and Management (ICITM), Oxford, UK, 7-9 March 2018; Institute of Electrical and Electronics Engineers (IEEE): Piscataway, NJ, USA, 2018; pp. 284-287.

60. Malico, I.; Gonçalves, A.C.; Sousa, A. Assessment of the availability of forest biomass for biofuels production in Southwestern Portugal. In Defect and Diffusion Forum; Trans Tech Publications: Kapellweg, Switzerland, 2016; Volume 371, pp. 121-127.

61. Obersteiner, M.; Böttcher, H.; Yamagata, Y. Terrestrial ecosystem management for climate change mitigation. Curr. Opin. Environ. Sustain. 2010, 2, 271-276. [CrossRef]

62. Winjum, J.K.; Dixon, R.K.; Schroeder, P.E. Estimating the global potential of forest and agroforest management practices to sequester carbon. Water Air Soil Pollut. 1992, 64, 213-227. [CrossRef]

63. Nunes, L.J.; Meireles, C.I.; Gomes, C.J.P.; Ribeiro, N.M.A. Forest Management and Climate Change Mitigation: A Review on Carbon Cycle Flow Models for the Sustainability of Resources. Sustainability 2019, 11, 5276. [CrossRef]

64. Newton, G.; Bernard, J.; Hubbard, R.; Allison, J.; Lowrance, R.; Gascho, G.; Gates, R.; Vellidis, G. Managing Manure Nutrients Through Multi-crop Forage Production. J. Dairy Sci. 2003, 86, 2243-2252. [CrossRef]

65. Moreno-Calles, A.I.; Casas, A.; García-Frapolli, E.; Torres-García, I. Traditional agroforestry systems of multi-crop "milpa" and "chichipera" cactus forest in the arid Tehuacán Valley, Mexico: Their management and role in people's subsistence. Agrofor. Syst. 2012, 84, 207-226. [CrossRef]

(C) 2020 by the authors. Licensee MDPI, Basel, Switzerland. This article is an open access article distributed under the terms and conditions of the Creative Commons Attribution (CC BY) license (http://creativecommons.org/licenses/by/4.0/). 